\title{
BARRIERS TO FINANCIAL INCLUSION: AN ISM MICMAC ANALYSIS
}

\author{
Dr. Santosh Kumar \\ Associate Professor \\ GITAM Institute of Management \\ GITAM (Deemed to be) University, India \\ E-mail: talksat@gmail.com \\ Dr. Gargi Pant Shukla \\ Associate Professor \\ Doon Business School, India \\ E-mail: gargipant87@gmail.com \\ Dr. Rakesh K Dhar Dubey \\ Assistant Professor \\ School of Management \\ IMS Unison University, India \\ E-mail: rakeshdhar77@gmail.com
}

\begin{abstract}
The policymakers should take a series of immediate actions to address the consequences of the Covid-19 pandemic in the path of the sustainable economy by reaching to every segment of the society to return the economy on track, financial inclusion (FI) is the only way to achieve the target. The study analyzes the obstacles in the path to achieve sustainable growth, which has been partitioned into two stages; the identification of barriers and investigation. The study has divided into three diverse stages: identification of barriers, interviews with specialists from industry, and framing an ISM model. Fifteen barriers have been identified in the achievement of goals of financial inclusion with four levels in ISM designed model. Not enough money, Lack of trust, High cost, Financial Illiteracy, Gender issues, Age factor, and Terms and conditions are factors of prime importance as they have very high driving as well as dependence power. Factors like Irregular income, Distance, and Legal identity are not showing a direct impact on other variables in the system, so these three factors may overlook by decision takers. Psychological and cultural barriers and Bank charges are very important barriers to high dependent driving power. These obstacles must require proper attention.
\end{abstract}

Keywords: Obstacles, Interpretive Structural Modeling (ISM), MICMAC, Financial Inclusion.

JEL Classification Codes: G00, G18, G32, H30 


\section{INTRODUCTION}

In the current situation of COVID-19, the globe is struggling to survive with better health and a sustainable economy. The virus has diseased over 12 million people worldwide and claimed nearly 600,000 lives globally As the Covid-19 scare shuts the world down for financial and economic activities. The pandemic has an uneven impact on the formal and informal sectors of the economy, staying home means not working and losing their employments. "To die from hunger or the infection" is a very genuine problem experienced by laborers in the informal area. The informal economic sector accounts for $90 \%$ of total employment in low-income nations, $67 \%$ in middleincome nations, and $18 \%$ in high-income nations. (ILO Geneva report 2018). The developing, and overpopulated economy, like India, is suffering badly due to the high impact in their informal sector. The policymakers should take a series of immediate actions to address the consequences of the Covid-19 pandemic in the path of the sustainable economy by supporting the informal economy as early as possible. It has become very important that the economic wellness schemes should reach every segment of the society to return the economy on track, financial inclusion (FI) is the only way to achieve this mammoth target. By didn't of the universal financial mission 2020 (UFA-2020) of the World Bank, still approx.1 billion global population are unbanked. The condition is more severe in developing economies like India.

The Huge portion of the population is out of reach from a formal credit system which leads to austere concern for the financial development of the country. The lack of financial awareness and financial literacy among the provincial population of the country is impeding the ballooning of the economy. The main objective of financial inclusion is to extend the financial and banking services to the un-served section of the society and the government is working more rigorously towards making it mainly available to the poor and rural population of the country. As per the recent report 2018, there is an increase of $20.3 \%$ in the position of rural households availing banking services in India as it is increased to $75.5 \%$ in the year 2018 as compared to $54.3 \%$ in the year 2011. (finclusion.org 2020). The recent data of the Reserve Bank of India on financial inclusion condition recommends that including rural regional banks' outlets in rural places extended over 52,000 as of March-2019, an increase of 3\% over March-2018.

Financial inclusion, financial education, and financial stability are three interrelated elements of the integrated strategy as the financial inclusion works from the supply side and works on providing access to various financial products and services, financial education feeds the demand side by providing information and spread awareness regarding various financial products and services available in the market. Financial inclusion and financial education together promote financial stability in the economy. Financial inclusion is defined as a process of facilitating financial services and products to the people from low income and weaker sections of the society at an affordable cost in a transparent manner, as defined by Dr. K.C. Chakrabarty, Deputy Governor of RBI - 2011.

As per the progress report of the Department of Financial Services, to facilitate more to the vulnerable groups' GOI have offered many schemes like Swabhimaan (to provide adequate banking facilities); Direct Benefit Transfer for LPG -DBTL (to curb leakages in the distribution system); Rupay Card (to participate in electronic payment system); USSD Based Mobile Banking (to offer the facility of mobile banking); Pradhan Mantri Jan-DhanYojana (to universal access to banking facility with at least one basic banking account for every household)

This analysis is therefore intended to establish, in the form of barriers, the factors affecting the growth of FI. Financial Inclusion is needed to reduce or remove certain sustainability obstacles in the long run. One of the preliminary attempts to research the reciprocal relationship between the entire obstacles in the FIs path is this article. The significant goal of this paper is to rank the 
barriers based on their predominance and examination the shared basic relationship of all chosen factors for the advancement of FI utilizing the Interpretive Structural Modeling (ISM) model an opinion from experts.

To give an efficient way to deal with the problem, the paper has been sectioned into the following segments; the detail of past literature along with the gap in research has been addressed in section 2, Section 3 offers a description of the research methodology. The development of the survey and the use of ISM is shrouded in segments 4 and 5 separately. The outcomes and recommendations have been shrouded in segment 6 while Section 7 presents the limitation and scope for the future.

\section{LITERATURE STUDY}

This section addresses numerous literature ties to FI and ISM understanding and obstacles to settin $\mathrm{g}$ a foundation for the research.

\section{FI and its barriers}

GOI and RBI have accorded high importance to Financial Inclusion to aid the comprehensive growth of the economy. There are still needs that should be covered to make financial inclusion more efficient and user friendly (Reddy, 2016) Financial inclusion has a positive and important effect on the country's GDP, the number of bank branches, and credit deposit ratios, although there has been no significant impact in India in the case of ATM growth (Iqbal \& Sami, 2017). Financial Inclusion increased after the implementation of Pradhan Mantri Jan Dhan Yojana (PMJDY), and the credit disbursement by banks and bank deposits increased (Tripathi \& Yadav, 2016). Determinants of borrowing from formal sources have been identified, and being male, having a bank account, and higher educational qualifications are positively correlated with the likelihood of formal borrowing (Mukhopadhyay2016). Role of Microfinance and its role in poverty eradication can be a parameter in the study (Dhakal \& Nepal, 2017; Iheduru \& Okoro, 2018). The regulator has to create a suitable regulatory environment to keep the interest of all the stakeholders (Garg \& Agarwal, 2014). Under the Financial Inclusion initiative, the performances of the bank are also measured (Thyagarajan \& Nair, 2016). The microfinance revolution needs to strengthen through social media to increase financial literacy and to promote financial sustainability (Hans, 2016).Only 33.86 percent of adults have a formal bank account in the year 2016 in Ethiopia, which is used for keeping money safe, send and receive payments, and to get credit services and foreign exchange services (Bazal \& Rao, 2017). Many rural people in south India are financially included and the social and personal factors are seen as key barriers to financial inclusion (Cnaan \& Moodithaya, 2012). In India, 50\% of the financially excluded populations are Muslims, though the foremost priority teaching of Islam is justice and equity in economic development (Beg \& Mullick, 2016). A Usage, Barrier, and access to financial inclusion are the three dimensions to calculate the degree of financial inclusion, out of these three dimensions access to financial inclusion is the most important dimension to measure the level of financial inclusion (Dara, 2016). Classification and analysis of the barriers to financial inclusion lead to a deeper understanding of financial inclusion. Lack of trust and social restriction caused by the informal transfer hamper saving in Latin America and creates supply-side barriers in financial inclusion (Serebrisky \& Cavallo, 2016).

\section{The Literature of ISM and MICMAC}

ISM and MICMAC analysis is used to identify and classify the quality dimensions of health care dimensions (Talib \& Rahman, 2015). TQM enablers along with IT resources were identified to establish the contextual relationship between them with the use of ISM and the dependency and 
driving power of the enablers is found out by MICMAC analysis (Khanam \& Siddiqui, 2015). To evolve the mutual relationship among knowledge Sharing Barriers (KSBs) the ISM methodology has been used (Sharma\& Singh, 2012). ISM is used to find out the key barriers in knowledge management and to develop a relationship amongst knowledge management in SMEs and to develop a model for establishing relationships among them (Chawan \& Vasudevan 2013). To evolve the mutual relationship among the Knowledge Management Technologies KMTs ISM has been used. The driving power is calculated to improve the effectiveness of Knowledge Management (Singh \& Singh, 2013). Barriers that affect the marketers on the rural market were highlighted and the interrelationships among these barriers were found and categorized based on their driving and dependence power by using ISM (Kumari \& Gupta 2014). ISM is used to construct a model to show how barriers in green marketing and green consumerism interact and affect consumer decision-making regarding green products (Nath \& Kumar 2014). ISM is used to identify the barriers to Green Business Models, GMBs (Abu Zeinab \& Arif, 2017). ISM model has been used to find the major barriers in Collaborative planning, forecasting, and replenishment were identified, and their interrelationship in CPFR executions with attention on technology-driven industries. (Panahifar \& Heavey, 2015).

Interpretative structural modeling (ISM) was applied to split the significant factors of constructor credentials in diverse levels (Chen \& Li 2014). ISM is used to study the major contributors that affect the execution of cost control in a firm and establish a hierarchical relationship between each other (Yunna \& Qing, 2012). ISM and MICMAC are used to understand the barriers to a successful implementation of supplier development activities (SDAs) and its mutual relationships between many enablers for supplier development based on driving and the dependence power (Dalvi \& Kant 2017). ISM model has been used to recognize the enablers in Commercial off-the-Shelf (COTS) by examining the complication of the arrangement as the components of the system (Ertas \& Smith, 2016).

With the growth and expansion of Financial Inclusion in India, sustainability is one of the key issues before a decision-maker. It is difficult for policymakers to remove the obstacles to the growth and expansion of financial inclusion in India. A very small amount of research has been done in the FI area. Researchers are unable to find any ISM-based literature or any other interactive model that would rate FI barriers. One of the preliminary attempts to fill the literature gap by the study. The fifteen barriers are found as shown in Table 1, which were based on past published literature.

Table 1. Factors for FIs

\begin{tabular}{|l|l|l|l|}
\hline $\begin{array}{l}\text { S. } \\
\text { No }\end{array}$ & Barrier & Description & Author \\
\hline 1 & Not enough money & $\begin{array}{l}\text { The most common cause for lack of a formal } \\
\text { source of money is not having a bank account, } \\
\text { only 41\% of adults have a saving account. }\end{array}$ & $\begin{array}{l}\text { Global Findex Report, 2014 } \\
\text { Bhuvana \& Vasantha 2016 }\end{array}$ \\
\hline 2 & Irregular income & $\begin{array}{l}\text { The main cause of the financial exclusion of } \\
\text { poor people is irregular income and various } \\
\text { uncertainties in cash flow. }\end{array}$ & Chauhan, 2013 \\
\hline
\end{tabular}




\begin{tabular}{|c|c|c|c|}
\hline 3 & Lack of trust & $\begin{array}{l}\text { Lack of trust in a formal financial institution by } \\
\text { unbanked rural people is one of the major } \\
\text { barriers to the growth of financial inclusion. }\end{array}$ & $\begin{array}{l}\text { Chauhan, } 2013 \\
\text { Bhuvana \&Vasantha } 2016 \\
\text { Global Findex Report, } 2014\end{array}$ \\
\hline 4 & $\begin{array}{l}\text { Macroeconomics } \\
\text { and bureaucratic } \\
\text { impediments }\end{array}$ & $\begin{array}{l}\text { The factor explains the role of Bureaucrats and } \\
\text { macroeconomic factors in financial Inclusion. }\end{array}$ & Suggested By experts \\
\hline 5 & High cost & $\begin{array}{l}\text { The high cost to reach the financial institution is } \\
\text { the major obstacle for financial inclusion. }\end{array}$ & $\begin{array}{l}\text { Bhuvana \& Vasantha, } 2016 \\
\text { Deepika, } 2015\end{array}$ \\
\hline 6 & Technology & $\begin{array}{l}\text { Making the people tech-savvy and maintaining } \\
\text { the security of data is a challenge. }\end{array}$ & $\begin{array}{l}\text { Bhuvana \&Vasantha, } 2016 \\
\text { Deepika, } 2015\end{array}$ \\
\hline 7 & Distance & $\begin{array}{l}\text { The most well-known limitation in FI is the } \\
\text { distance of the bank in the rural part of the } \\
\text { country. It is extremely hard to come to the } \\
\text { closest branch because of high transportation } \\
\text { costs. }\end{array}$ & $\begin{array}{l}\text { Chauhan, } 2013 \\
\text { Bhuvana \& Vasantha, } 2016 \\
\text { Deepika, 2015 } \\
\text { Global Findex Report, } 2014\end{array}$ \\
\hline 8 & Policy regulations & $\begin{array}{l}\text { Another frequently faced barrier is a failure to } \\
\text { give documentation, for example, character } \\
\text { confirmation which is required by formal money } \\
\text { related establishments. A sufficient identity } \\
\text { check is required by banks before opening } \\
\text { accounts. }\end{array}$ & $\begin{array}{l}\text { Chauhan, } 2013 \\
\text { Bhuvana \&Vasantha, } 2016 \\
\text { Gupta, } 2015\end{array}$ \\
\hline 9 & Financial Illiteracy & $\begin{array}{l}\text { Illiteracy about financial services and products } \\
\text { available; limits the awareness level and ability } \\
\text { to overcome financial problems for the poor. }\end{array}$ & $\begin{array}{l}\text { Chauhan, } 2013 \\
\text { Gupta, } 2015\end{array}$ \\
\hline 10 & Gender issues & $\begin{array}{l}\text { Ladies who don't have fixed property must look } \\
\text { for male assurance of obtaining and admittance } \\
\text { to credit. }\end{array}$ & $\begin{array}{l}\text { Gupta, } 2015 \\
\text { RBI Report, } 2008\end{array}$ \\
\hline 11 & Legal identity & $\begin{array}{l}\text { The absence of lawful proofs like identity cards, } \\
\text { election cards, or any other government proof } \\
\text { reject ladies, and political refugees and migrant } \\
\text { laborers from getting financial help confine the } \\
\text { development of FI. }\end{array}$ & $\begin{array}{l}\text { Gupta, } 2015 \\
\text { RBI Report, } 2008 \\
\text { Global Findex Report, } 2014\end{array}$ \\
\hline 12 & $\begin{array}{l}\text { Psychological and } \\
\text { cultural barriers }\end{array}$ & $\begin{array}{l}\text { Social and religious restrictions for banking have } \\
\text { been seen alongside the inclination that banks } \\
\text { are not intrigued to serve poor and financially } \\
\text { excluded people which led them to self- } \\
\text { exclusion for financial inclusion. }\end{array}$ & $\begin{array}{l}\text { Bhuvana \&Vasantha, } 2016 \\
\text { RBI Report, } 2008\end{array}$ \\
\hline 13 & Bank charges & $\begin{array}{l}\text { Banking transactions are free in certain nations } \\
\text { as long as the record has an adequate fund to } \\
\text { meet the transaction. The other banking charges } \\
\text { affect people with low-income groups and create } \\
\text { a financial barrier to inclusion. }\end{array}$ & $\begin{array}{l}\text { Chauhan, } 2013 \\
\text { RBI Report, } 2008\end{array}$ \\
\hline
\end{tabular}




\begin{tabular}{|l|l|l|l|}
\hline 14 & Age factor & $\begin{array}{l}\text { Usually, the middle-aged active population is } \\
\text { targeted by financial service providers, and older } \\
\text { age people find it difficult to the banking } \\
\text { transaction. }\end{array}$ & $\begin{array}{l}\text { Gupta, 2015 } \\
\text { RBI Report, 2008 }\end{array}$ \\
\hline 15 & $\begin{array}{l}\text { Terms } \\
\text { conditions }\end{array}$ & $\begin{array}{l}\text { Maintaining the minimum account balance and } \\
\text { other terms conditions identifying with } \\
\text { utilization of account regularly discourage } \\
\text { individuals from utilizing such items. }\end{array}$ & RBI Report, 2008 \\
\hline
\end{tabular}

\section{MATERIALS AND METHODS}

The segment clarifies the total research procedure selected to tackle the distinguished problems of the study.

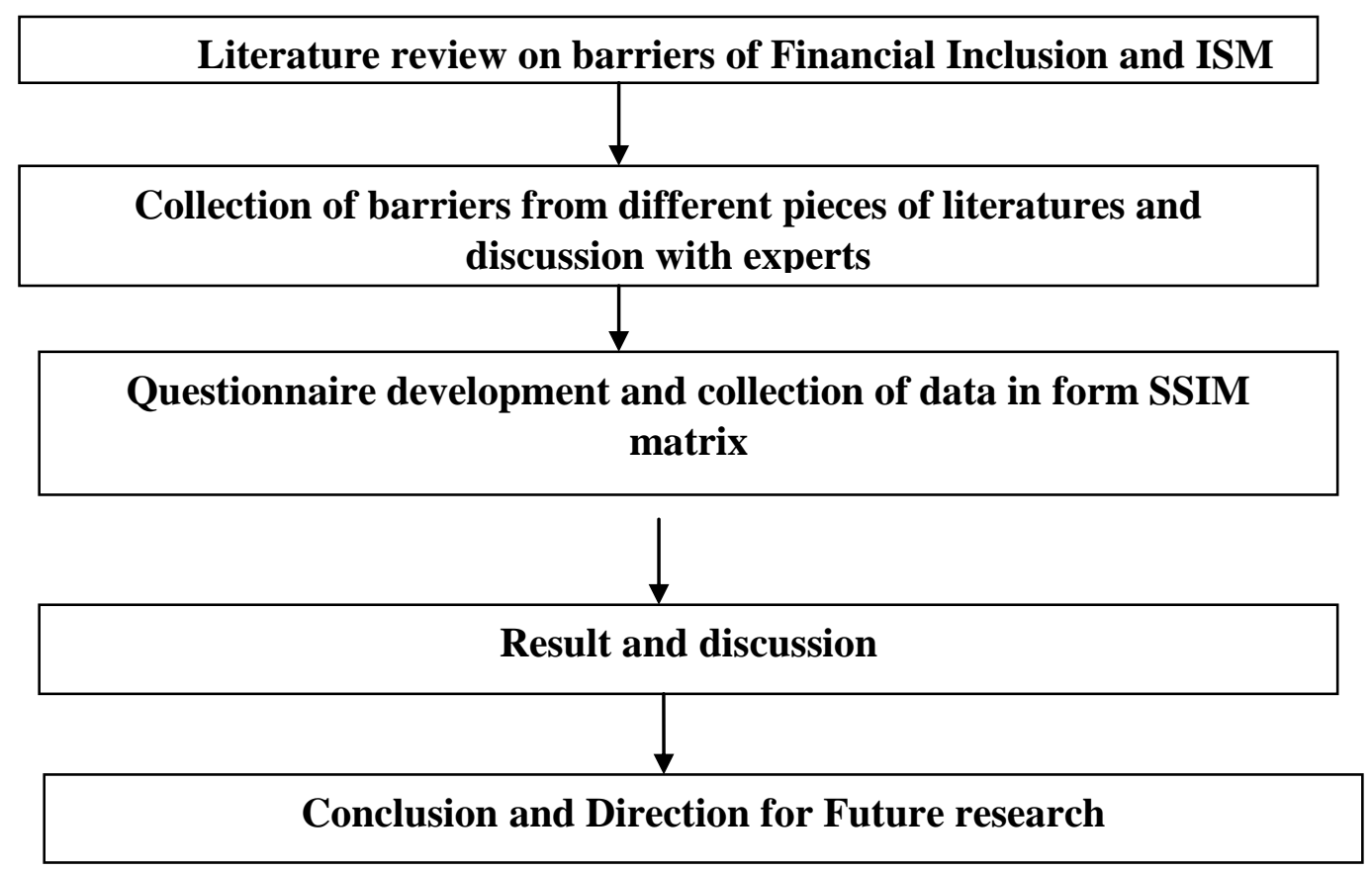

Figure 1. Clarifies the systematic approach followed in the research

Due to the high growth in the Indian economy, the need for credit has been increased and still growing for the last many decades. Such demand for credit forces GOI to achieve goals of financial inclusion.

ISM follows a well-designed systematic process, the steps involved in the ISM method are extracted from; Kannan and Devika (2010); Kumari and Gupta (2014); Kumar and Sharma (2018); Kumar and Shukla (2019) and are as follows:

1: Create a group of selected obstacles in the study.

2: In the step, a pairwise contextual exam is conducted among all the factors selected.

3: For a pairwise association between variables, a Structural Self-Interaction Matrix (SSIM) is developed.

4: A matrix of reachability is established, and transitivity is tested. The ISM transitivity hypothesis states that if factor A is connected to factor B and factor B is conn ected to factor $\mathrm{C}$, and then $\mathrm{A}$ is fundamentally connected with factor $\mathrm{C}$. 
5: The reachability matrix is classified into several stages.

6: By removing transitive ties based on the connotation found in the reachability matrix, a directional graph is generated.

7: The digraph resulting from this is translated into an ISM

8: As an ISM model, the digraph was further developed, and tested for "conceptual inconsistency." If possible, simple changes can be made.

9: The MICMAC review is intended to identify all obstacles into four clusters. The measures discu ssed above are shown in Figure 2.

Financial Inclusion's execution entails obstacles and difficulties on the demand side and supply side. The main challenges are the degree of literacy, technology, high cost, gender inequality, and bank charges. As shown in table 1, fifteen obstacles for research are gathered from the literature survey and expert opinions.

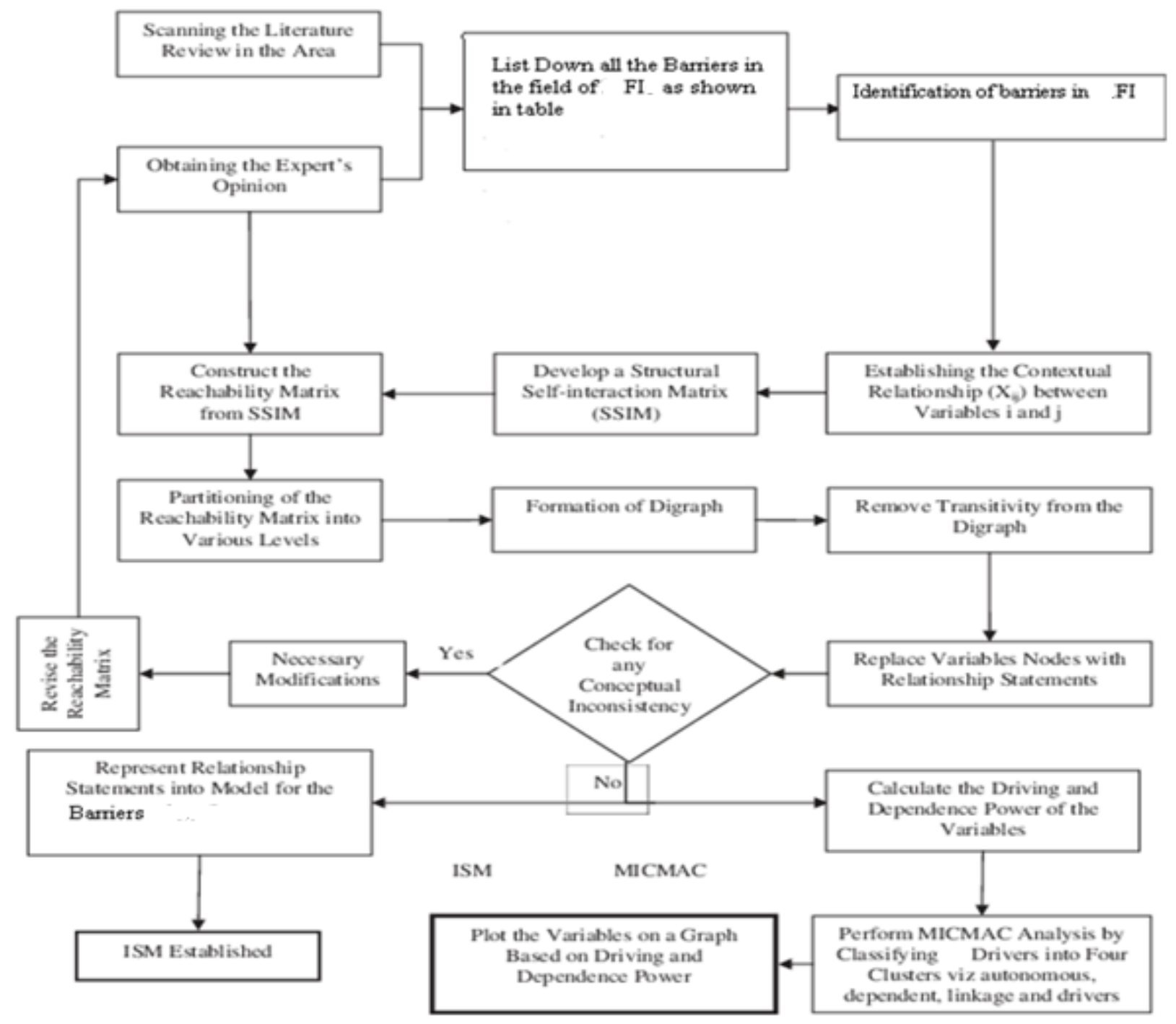

Modified from Diabat et al. (2013)

Figure 2. Flow diagram for ISM model planning. 


\section{FORMATION OF THE QUESTIONNAIRE}

The development towards the achievement of FI in the country is very unusual because of highly diversified social variables in other developed nations. The main aim of the research is to stress the relevance of ISM, a communication method for composite circumstances, for policymakers in the rapid development of FI. To examine the most important barriers to the achievement of FI, fifteen barriers are taken from literature and by discussion from experts. The respondents are senior industry professionals and senior academicians from various universities. At first 25 specialists were identified and contacted, yet after repeated correspondence with them, just fourteen was associated with the study. All individual reactions were merged and sent to two specialists to get the last reaction. These specialists were recognized by contact of analysts from the various areas across India with at least field knowledge of 10 years. At last, one response was recorded an expert's reaction, and brainstorming between researchers and peer groups.

\section{IMPLEMENTATION OF ISM}

The Structural self-interaction matrix, SSIM, has been developed as the first step of ISM formation. The SSIM matrix represents the contextual relationship between two barriers (I and $\mathrm{j}$ ) based on expert opinion.

To demonstrate the pairwise directional relation between two barriers, 4 symbols, V, A, O, and X; were used Symbol $\mathrm{V}$ indicates factor $\mathrm{I}$ will assist in achieving factor $\mathrm{j}$, Symbol A indicates factor $\mathrm{j}$ will assist in achieving factor I, Symbol $\mathrm{x}$ indicates factor $\mathrm{j}$ and I will assist in achieving each other, and Symbol $\mathrm{O}$ indicates no relationship between factor $\mathrm{j}$ and $\mathrm{I}$.

The SSIM for the selected factors for FI is given in Table 2.

Table 2. Structural self-interaction matrix (SSIM)

\begin{tabular}{|c|c|c|c|c|c|c|c|c|c|c|c|c|c|c|c|c|}
\hline S.No. & Barrier & 15 & 14 & 13 & 12 & 11 & 10 & 9 & 8 & 7 & 6 & 5 & 4 & 3 & 2 & 1 \\
\hline 1 & Not enough money & $X$ & A & $\mathrm{X}$ & $\mathrm{O}$ & $\mathrm{O}$ & $X$ & $\mathrm{X}$ & $\mathrm{O}$ & $\mathrm{O}$ & $\mathrm{O}$ & $\mathrm{X}$ & $\mathrm{O}$ & $\mathrm{O}$ & $X$ & $\mathrm{X}$ \\
\hline 2 & Irregular income & $\mathrm{X}$ & A & $\mathrm{V}$ & $\mathrm{O}$ & $\mathrm{O}$ & A & $\mathrm{V}$ & $\mathrm{O}$ & $\mathrm{O}$ & $\mathrm{O}$ & $\mathrm{O}$ & A & $\mathrm{O}$ & $X$ & \\
\hline 3 & Lack of trust & $\mathrm{O}$ & A & $\mathrm{V}$ & $\mathrm{A}$ & $\mathrm{O}$ & A & $\mathrm{X}$ & $\mathrm{X}$ & $\mathrm{A}$ & $X$ & A & $\mathrm{A}$ & $X$ & & \\
\hline 4 & $\begin{array}{l}\text { Macroeconomics and } \\
\text { bureaucratic } \\
\text { impediments }\end{array}$ & $\mathrm{V}$ & $\mathrm{O}$ & $\mathrm{V}$ & $\mathrm{O}$ & $\mathrm{O}$ & $\mathrm{O}$ & $\mathrm{V}$ & $X$ & $\mathrm{O}$ & $\mathrm{V}$ & $\mathrm{V}$ & $X$ & & & \\
\hline 5 & High cost & $X$ & $\mathrm{O}$ & $\mathrm{X}$ & $\mathrm{V}$ & $\mathrm{O}$ & $\mathrm{A}$ & A & $\mathrm{X}$ & $\mathrm{O}$ & $X$ & $X$ & & & & \\
\hline 6 & Technology & $\mathrm{V}$ & $X$ & $X$ & $\mathrm{~A}$ & $\mathrm{O}$ & $\mathrm{A}$ & $\mathrm{X}$ & A & $\mathrm{V}$ & $\mathrm{X}$ & & & & & \\
\hline 7 & Distance & $\mathrm{O}$ & $X$ & $\mathrm{O}$ & $\mathrm{V}$ & $\mathrm{O}$ & $\mathrm{V}$ & $\mathrm{O}$ & $\mathrm{O}$ & $\mathrm{X}$ & & & & & & \\
\hline 8 & Policy regulations & $\mathrm{X}$ & $\mathrm{O}$ & $\mathrm{V}$ & $\mathrm{O}$ & $\mathrm{O}$ & $\mathrm{O}$ & $\mathrm{X}$ & $\mathrm{X}$ & & & & & & & \\
\hline 9 & Financial Illiteracy & $\mathrm{X}$ & A & $\mathrm{O}$ & A & $\mathrm{O}$ & $X$ & $\mathrm{X}$ & & & & & & & & \\
\hline 10 & Gender issues & $\mathrm{V}$ & $\mathrm{V}$ & $\mathrm{V}$ & $\mathrm{X}$ & $\mathrm{O}$ & $X$ & & & & & & & & & \\
\hline 11 & Legal identity & $X$ & $\mathrm{O}$ & $\mathrm{O}$ & $\mathrm{X}$ & $\mathrm{X}$ & & & & & & & & & & \\
\hline 12 & $\begin{array}{l}\text { Psychological } \\
\text { cultural barriers }\end{array}$ & $X$ & A & A & $X$ & & & & & & & & & & & \\
\hline 13 & Bank charges & $\mathrm{X}$ & A & $X$ & & & & & & & & & & & & \\
\hline 14 & Age factor & $\mathrm{V}$ & $\mathrm{X}$ & & & & & & & & & & & & & \\
\hline 15 & Terms and conditions & $\mathrm{X}$ & & & & & & & & & & & & & & \\
\hline
\end{tabular}


The matrix of reachability is generated by changing each cell's above matrix details into binary digits, i.e. 1 or 0 .The conversion laws are as follows:

- The Value of V of (i,j) in the SSIM becomes 1 and the $(j, i)$ entry becomes 0 , inthe reachability matrix.

- The Value of A of (i,j) in the SSIM becomes 0 and the $(j, i)$ entry becomes 1 , in the reachability matrix.

- The Value of $X$ of $(i, j)$ in the SSIM becomes 1 and the $(j, i)$ entry also becomes 1 , in the reachability matrix.

- The Value of $O$ of $(i, j)$ in the SSIM becomes 0 and the $(j, i)$ entry becomes 0 , in the reachability matrix.

The barriers transitivity has been checked and the final matrix of reachability is generated and shown in table 3 below.

Table 3. Reachability Matrix after Transitivity

\begin{tabular}{|l|l|l|l|l|l|l|l|l|l|l|l|l|l|l|l|}
\hline S.No. & $\mathbf{1}$ & $\mathbf{2}$ & $\mathbf{3}$ & $\mathbf{4}$ & $\mathbf{5}$ & $\mathbf{6}$ & $\mathbf{7}$ & $\mathbf{8}$ & $\mathbf{9}$ & $\mathbf{1 0}$ & $\mathbf{1 1}$ & $\mathbf{1 2}$ & $\mathbf{1 3}$ & $\mathbf{1 4}$ & $\mathbf{1 5}$ \\
\hline $\mathbf{1}$ & 1 & 1 & 0 & 0 & 1 & 1 & 0 & 0 & 1 & 1 & 0 & 0 & 1 & 1 & 1 \\
\hline $\mathbf{2}$ & 1 & 1 & 0 & 0 & 0 & 0 & 0 & 0 & 1 & 1 & 0 & 0 & 1 & 1 & 1 \\
\hline $\mathbf{3}$ & 0 & 0 & 1 & 1 & 1 & 1 & 1 & 1 & 1 & 0 & 0 & 0 & 1 & 0 & 1 \\
\hline $\mathbf{4}$ & 0 & 1 & 1 & 1 & 1 & 1 & 0 & 1 & 1 & 0 & 0 & 0 & 1 & 0 & 1 \\
\hline $\mathbf{5}$ & 1 & 0 & 1 & 0 & 1 & 1 & 0 & 1 & 0 & 0 & 0 & 1 & 1 & 1 & 1 \\
\hline $\mathbf{6}$ & 0 & 0 & 1 & 0 & 1 & 1 & 1 & 0 & 1 & 1 & 0 & 0 & 1 & 1 & 1 \\
\hline $\mathbf{7}$ & 0 & 0 & 1 & 0 & 0 & 0 & 1 & 0 & 0 & 1 & 0 & 1 & 0 & 1 & 0 \\
\hline $\mathbf{8}$ & 0 & 0 & 1 & 1 & 1 & 1 & 0 & 1 & 1 & 1 & 0 & 0 & 1 & 0 & 1 \\
\hline $\mathbf{9}$ & 1 & 0 & 1 & 0 & 1 & 1 & 0 & 1 & 1 & 1 & 0 & 0 & 0 & 1 & 1 \\
\hline $\mathbf{1 0}$ & 1 & 1 & 1 & 0 & 1 & 1 & 0 & 0 & 1 & 1 & 0 & 1 & 1 & 1 & 1 \\
\hline $\mathbf{1 1}$ & 0 & 0 & 0 & 0 & 0 & 0 & 0 & 0 & 0 & 0 & 1 & 1 & 0 & 0 & 1 \\
\hline $\mathbf{1 2}$ & 0 & 0 & 1 & 0 & 0 & 1 & 0 & 0 & 1 & 1 & 1 & 1 & 0 & 0 & 1 \\
\hline $\mathbf{1 3}$ & 1 & 0 & 0 & 0 & 1 & 1 & 0 & 0 & 0 & 0 & 0 & 1 & 1 & 0 & 1 \\
\hline $\mathbf{1 4}$ & 1 & 1 & 1 & 0 & 0 & 1 & 1 & 0 & 1 & 1 & 0 & 1 & 1 & 1 & 1 \\
\hline $\mathbf{1 5}$ & 1 & 1 & 0 & 0 & 1 & 0 & 0 & 1 & 1 & 0 & 1 & 1 & 1 & 0 & 1 \\
\hline
\end{tabular}

The reachability and antecedent set for each identified barrier are determined from the last framework (Warfield, 1974). The reachability set of a factor incorporates the component itself and different components, which can encourage accomplishing the factor. The antecedent set for a component incorporates the factor itself and different components, which are accomplished with the assistance of the factor. The intersection values are determined for two sets of the apparent multitude of components. The barriers with the same intersection and reachability set are kept on the peak level in the hierarchy of ISM, which would not show any impact on some other variables over their level. After, these recognized and leveled components will be erased from other leftover 
sets of components. The level recognizable process of all chosen barriers is finished in four-level iterations, as given in table 4 underneath. The cycle is tenacious till every factor got leveled in ISM. The recognized levels of elements are utilized in building the digraph of the last, model of the ISM.

Table 4. Barrier stage partitions: Iteration I to Iteration IV

\begin{tabular}{|l|l|l|l|l|}
\hline $\begin{array}{l}\text { Key } \\
\text { Factors }\end{array}$ & Reachability sets & Antecedent sets & Intersecting sets & Iteration \\
\hline 11 & $11,12,15$ & $11,12,15$ & $11,12,15$ & I \\
\hline 12 & $11,12,15$ & $11,12,15$ & $11,12,15$ & I \\
\hline 15 & $11,12,15$ & $11,12,15$ & $11,12,15$ & I \\
\hline 1 & $1,2,5,8,9,13$ & $1,2,3,4,5,6,8,9,10,11,12,13,14,15$ & $1,2,5,8,9,13$ & II \\
\hline 2 & $1,2,5,8,9,13$ & $1,2,3,4,5,6,8,9,10,11,12,13,14,15$ & $1,2,5,8,9,13$ & II \\
\hline 5 & $1,2,5,8,9,13$ & $1,2,3,4,5,6,8,9,10,11,12,13,14,15$ & $1,2,5,8,9,13$ & II \\
\hline 8 & $1,2,5,8,9,13$ & $1,2,3,4,5,6,8,9,10,11,12,13,14,15$ & $1,2,5,8,9,13$ & II \\
\hline 9 & $1,2,5,8,9,13$ & $1,2,3,4,5,6,8,9,10,11,12,13,14,15$ & $1,2,5,8,9,13$ & II \\
\hline 13 & $1,2,5,8,9,13$ & $1,2,3,4,5,6,8,9,10,11,12,13,14,15$ & $1,2,5,8,9,13$ & II \\
\hline 10 & 10 & $1,7,8,9,10,12$ & 10 & III \\
\hline 14 & 14 & $1,3,4,5,6,8,9,10,12,13,14$ & 14 & III \\
\hline 3 & $3,4,6,7$, & $3,4,5,6,7,8,9,10,12,14$ & $3,4,6,7$ & IV \\
\hline 4 & $3,4,6,7$, & $3,4,5,6,7,8,9,10,12,14$ & $3,4,6,7$ & IV \\
\hline 6 & $3,4,6,7$, & $3,4,5,6,7,8,9,10,12,14$ & $3,4,6,7$ & IV \\
\hline 7 & $3,4,6,7$, & $3,4,5,6,7,8,9,10,12,14$ & $3,4,6,7$ & IV \\
\hline
\end{tabular}

The model structure has been shaped as given in fig 3 beneath. The relationship between the components $\mathrm{j}$ and $\mathrm{I}$ are uncovered by an arrow point in the subsequent diagram is known as a digraph, at last, considered as the ISM model. 


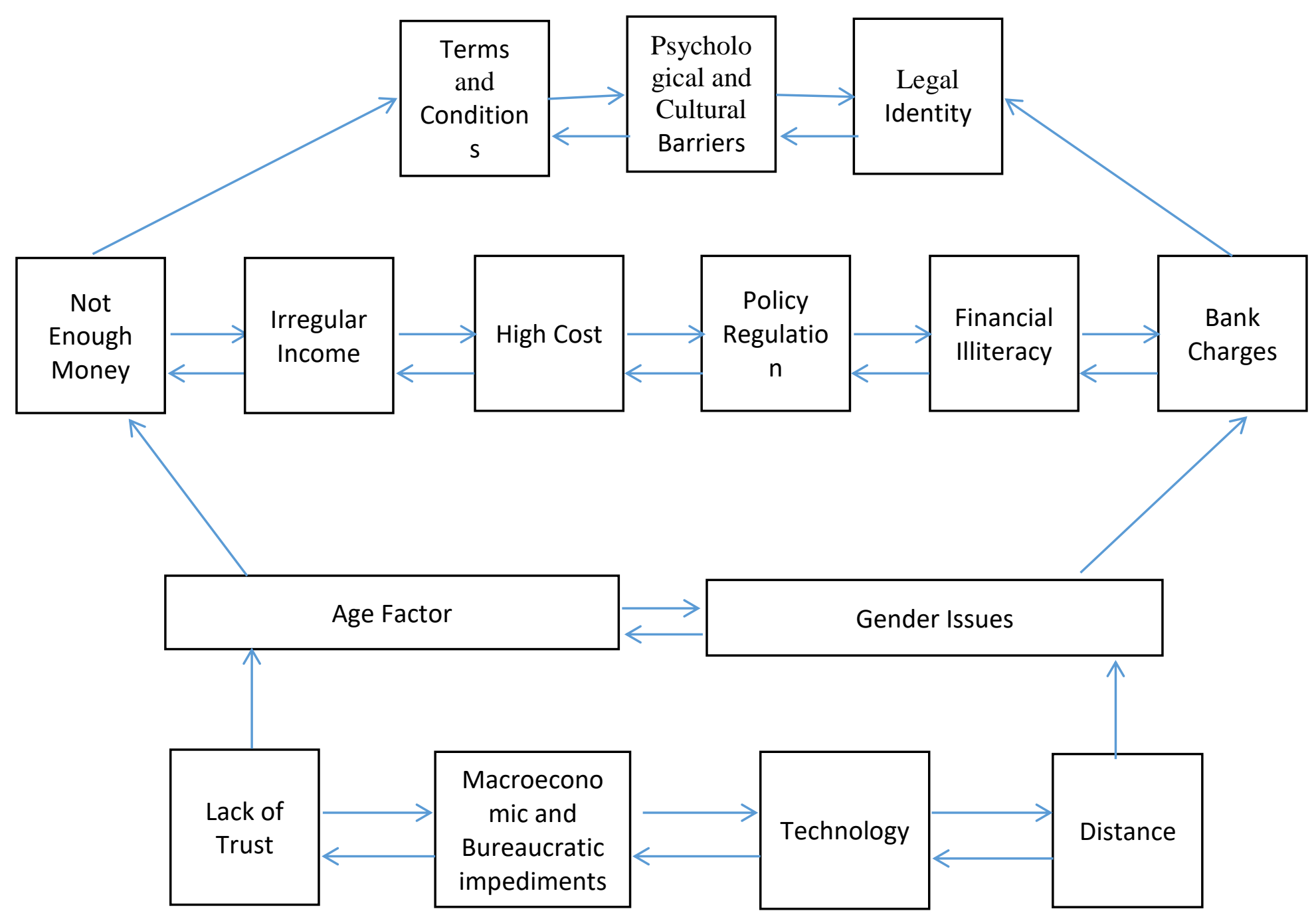

Figure 3. ISM based model for barriers

MICMAC i.e."Matricesd' Impacts Croises Multiplication. Appliqué a UN Classement "depends on the multiplication standard of a lattice (Sharma et al., 2012). The focal thought of MICMAC is to locate the driving and the dependence intensity of a factor in the research, as given in table 5. The selected factors have been segregated into four particular classes based on their driving and dependence power; the classifications are:

- Quadrant I (Autonomous barriers): The barriers in this quadrant have feeble dependence just as driving force. These elements might be withdrawn from the general structure.

- Quadrant II (Dependent barriers): The components with high dependence, however frail driving forces are falling into this classification.

- Quadrant III (Linkage barriers): The components with strong dependence and driving power are falling into this quadrant. They show good effects on the system as even a small change will have a direct impact on the remaining barriers.

- Quadrant IV (Independent barriers): The factors with feeble dependence power but with high driving power are part of this classification. These components generally show a good impact on the system without much impact by other factors of the system. 
Table 5. Strength of dependency and driving strength for barriers

\begin{tabular}{|l|l|l|}
\hline Barrier & Dependence & Driving \\
\hline 1 & 3 & 3 \\
\hline 2 & 8 & 7 \\
\hline 3 & 14 & 9 \\
\hline 4 & 8 & 9 \\
\hline 5 & 6 & 7 \\
\hline 6 & 10 & 9 \\
\hline 7 & 6 & 9 \\
\hline 8 & 11 & 9 \\
\hline 9 & 11 & 6 \\
\hline 10 & 9 & 11 \\
\hline 11 & 8 & 11 \\
\hline 12 & 10 & 9 \\
\hline 13 & 3 & 9 \\
\hline 14 & 11 & 9 \\
\hline 15 & 4 & 5 \\
\hline
\end{tabular}

The final ISM model, shown in figure 3, explains four distinct levels of factors with a Lack of trust (B3), Macroeconomic and bureaucratic impediments (B4), Technology (B6), and Distance (B7) at the base. Legal identity (B11), Psychological and cultural barriers (B12) and Bank Charges (B13) barriers are on the upper most in the hierarchy with the highest dependency control. As needs be, the diagram dependence power versus driving factors for all the elements is made and appeared in Fig 4. The chosen barriers are dispersed in four quadrants of the chart. Suggestions and clarifications of the apparent multitude of results are explained in the further section.

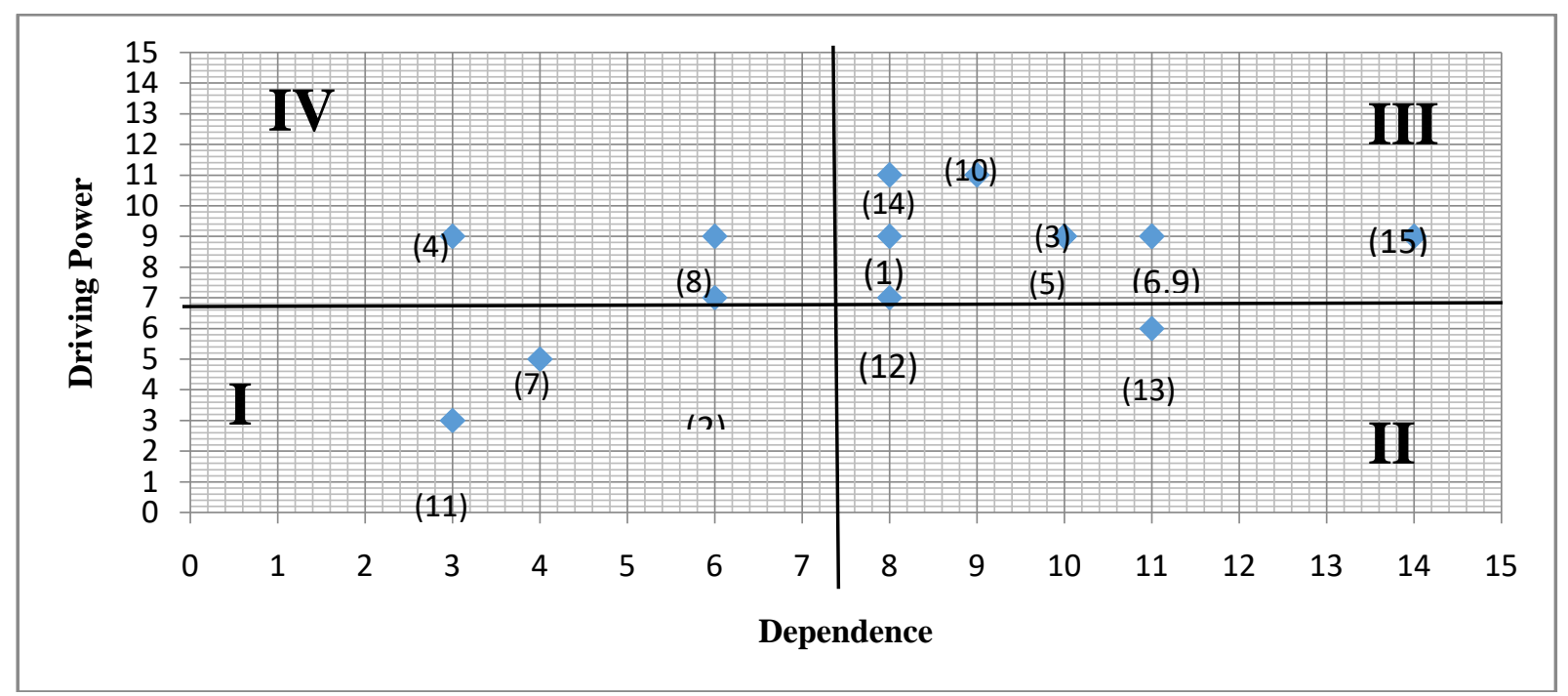

Figure 4. Barrier Dependency and Driving Diagram

\section{OUTCOME AND SUGGESTION}

The growth rate towards the achievement of goals of financial inclusion in the country is satisfactory but still, the disparity exists in the population, make an issue in sustainable and 
complete growth. Elimination and decrease of such difference are basic for the nation to accomplish huge objectives, like Jan Dhan Yojana, Atal Pension Yojana, Pradhan mantry Beema Yojana, and many more. More overachieving all goals of FI isn't a simple errand for the policymakers and there exist numerous hindrances in the customary strategies. Without knowing the details of these obstacles, no one can assure 100\% achievement of FI. This examination, because of an ideal positioning model for recognizable proof of barriers in the respects, gotten from literature and on counsel with industry specialists. The study is one of the essential endeavors in the field to make an ISM model show the linkage between all these recognized deterrents. The consequence of this investigation can make objectives accomplishment of FI smooth and simple, by featuring the significance of driving barriers. The force-based chart framed by the MICMAC process gives a comprehension of the overall significance and relationship of the recognized barriers. The findings of the research have been given below.

- Irregular income (B2), Distance (B7), and Legal identity (B11) are falling in quadrant I of the MICMAC graph. These components don't have a direct effect on other selected factors in the framework. They can be constrained by the control of different components, so these three variables may ignore by regulators. Components like distance and legal identity can't be controlled under the umbrella of Financial Inclusion, enough though the fact that they can be an obstruction in way of the accomplishment of objectives.

- Barriers like, Bank charges (B13) and Psychological and cultural barriers (B12) and are falling in quadrant II in the MICMAC graph. They are very important barriers to high dependent driving power. These obstacles must require proper attention.

- Not enough money (B1), Lack of trust (B3), High cost (B5), Financial Illiteracy (B9), Gender issues (B10), Age factor (B14), and Terms and conditions (B15) are falling in the third quadrant for example Linkage empowering agent. Such factors are of prime significance as they have exceptionally high driving and dependence capabilities.

- The remaining two of the factors, Macroeconomic and bureaucratic impediments (B4) and Policy regulations (B8), are high in driving, and fall in the fourth quadrant. They are acting as causing operator and less affected by the framework as an entirety are high in driving, and fall in the fourth quadrant.

Even though barriers like Distance and legal Identity are very significant elements for the accomplishment of objectives of Financial Inclusion in the nation, however, can't be legitimately constrained by the regulators in this respect because of their limitations. A few barriers like irregular income might not affect the entire framework.

Financial Inclusion factors don't just take a significant part in individual growth yet additionally the sustainable development of the economy of the country. Disparities in finance awareness are even continuing in developed nations. Education and un-awareness of financial services aregetting extremely critical for developing nations. A sustainable economic structure can be achieved by eliminating the obstacles in the path of the goals of FI. The strategy makers ought to disregard the autonomous class of barriers while taking decisions for the business. The strategy makers should make provisions for advertisement and promotion of the benefits of the financial inclusion of the common public.

\section{LIMITATION AND SCOPE OF FUTURE STUDY}

In this paper, ISM and MICMAC structure has been created with fifteen components as barriers to the accomplishment of the FI in India. A few factors have been recognized however not considered in the research because of appropriate reasonableness to the objective of the study. The future extent of this research is to propose a technique for control of barriers for smooth implementation and achievement of Financial Inclusion. 


\section{REFERENCES}

Abuzeinabet., A., Arif, M., \& Qadri, M.A. (2017). Barriers to MNEs green business models in the UK construction sector: An ISM analysis, Journal of Cleaner Production,160, 2737. https://doi.org/10.1016/j.jclepro.2017.01.00

Bazal, U., A \& Rao, S. K. (2017). Financial Inclusion in Ethiopia. Available, International Journal of Economics and Finance, 9(4), 191-201.

Beg, S., \& Mullick, H. N. (2016). Increasing Financial Inclusion Through Islamic Banking In India, International Journal of Business Management \& Research, 6(1), 27-34.

Bhuvana, M., \& Vasantha, S. (2016). Dimensions for Measuring Financial Inclusion in the Rural Areas of Tamil Nadu, Indian Journal of Science and Technology, 9(32), 1-8. https://doi.org/10.17485/ijst/2016/v9i32/98663

Chauhan, A. A. (2013). A study on overview of Financial Inclusion in India, Indian Journal of Applied Research, 3(12), 351-353. https://doi.org/10.15373/2249555X/DEC2013/106

Chawan, A. N., \& Vasudevan, H. (2013). Modeling Knowledge Management Barriers in the Indian Manufacturing SMEs Using ISM Approach, The IUP Journal of Knowledge Management, 11(4), 36-52.

Chen, L., \& Li, B. (2014). Research on the Affecting Factors of Constructor Certificate Attachment and Countermeasures Based on ISM Analysis, Conference paper presented in 2014 International Conference on Construction and Real Estate Management.

Cnaan, R. A., Moodithaya, M. S., \& Handy, F. (2012). Financial inclusion: Lessons from rural South India. Journal of Social Policy, 41(1), 183-205 http://dx.doi.org/10.1017/S0047279411000377

Dalvi, V., M., \& Kant, R. (2017). Modelling supplier development enablers: an integrated ISMFMICMAC approach, International Journal of Management Science and Engineering Management, 12(2), 75-83. https://doi.org/10.1080/17509653.2017.1312581

Dara, R. N. (2016). Multidimensional Index Measures of Digital Financial Inclusion in Emerging Markets: A Case of India, International Research Journal of Marketing and Economics, 3(6), 10-29.

Dhakal, C., \& Nepal, G. (2017). Microfinance Services and Poverty Level of Rural Farmers of Syangja District of Nepal. International Journal of Accounting \& Finance Review, 1(1), 31-41. https://doi.org/10.46281/ijafr.v1i1.16.

Ertas, A., Smith, M. W., Tate, D., Lawson, W. D., \& Baturalp, T. B. (2016). Complexity of system maintainability analysis based on the interpretive structural modeling methodology: Transdisciplinary approach. Journal of Systems Science and Systems Engineering, 25(2), 254-268. https://doi.org/10.1007/s11518-016-5310-8 
Garg, S. \& Agarwal, P. (2014). Financial Inclusion in India - a Review of Initiatives and Achievements, IOSR Journal of Business and Management, 16(6), 52-61.

Global Findex Report. (2014). Measuring Financial Inclusion around the World, World Bank Publication series. Retrieved from http://pubdocs.worldbank.org/en/681361466184854434/2014-Global-Findex-ReportDKSV.pdf

Gupta, D. (2015). Key Barriers Faced in Implementing Financial Inclusion, International Journal of Engineering Technology, Management and Applied Sciences, 3(1), 171-174.

Hans, B. V. (2016). Initiatives and Impact of Financial Inclusion in India, Journal of Exclusive Management Science, 5(10), 1-6.

Iheduru, N. G., \& Okoro, C. U. (2018). Macroeconomic Variables and Retained Earnings of Quoted Manufacturing Firms in Nigeria: A Time Variant Study. International Journal of Accounting \& Finance Review, 3(1), 33-47. https://doi.org/10.46281/ijafr.v3i1.29

ILO report. (2018). Women and Men in the Informal Economy: A Statistical Picture (third edition, Geneva): Retrieved from https://www.ilo.org/wcmsp5/groups/public/--dgreports/---dcomm/documents/publication/wcms_626831.pdf

Iqbal. A. B., \& Sami, S. (2017). Role of banks in financial inclusion in India. Contaduría y Administración, 62(2), 645-656. http://dx.doi.org/10.1016/j.cya.2017.01.007

Kannan G, Devika, K., \& Noorul, H. A. (2010). Analyzing supplier development criteria for an automobile industry. Industrial Management \& Data Systems, 110(1), 43-62.

Khanam, S, Siddiqui, J., \& Talib, F. (2015). Modeling the TQM enablers and IT resources in the ICT industry: An ISM-MICMAC approach, International Journal of Information Systems and Management (IJISAM), 1(3), 195-218.

Kumar, S., \& Sharma, R. (2018). Key barriers in the growth of rural health care: an ISMMICMAC approach, Benchmarking: An International Journal, 25(7), 2169-2183. https://doi.org/10.1108/BIJ-05-2017-0095

Kumar, S., Shukla, G.P., \& Sharma, R. (2019). Analysis of key barriers in retirement planning: An approach based on interpretive structural modeling, Journal of Modelling in Management, 14(4), 972-986. https://doi.org/10.1108/JM2-09-2018-0134

Kumari, P., Gupta, N., \& Sindhu, S. (2014). Modeling the Barriers to Rural Marketing Using the Interpretive Structural Modeling Approach, The IUP Journal of Marketing Management, 13(3), 7-30.

Mukhopadhyay, P. J. (2016). Financial Inclusion in India: A Demand-side Approach, Economic and political weekly, 51(49), 46-54. 
Nath, V., Kumar, R., Agrawal, R., Gautam, A., \& Sharma, V. (2014). Impediments to Adoption of Green Products: An ISM Analysis, Journal of Promotion Management, 20(5), 501520. https://doi.org/10.1080/10496491.2014.946200

Panahifar, F., Heavey, C., Byrne, P., \& Fazlollahtabar, H. (2015). A framework for Collaborative Planning, Forecasting, and Replenishment (CPFR) - State of the Art. Journal of Enterprise Information Management, 28(1),1-36. https://doi.org/10.1108/JEIM-09-2014-0092

RBI Report. (2008). Financial Inclusion, Reserve Bank of India Publication series. Retrieved from https://www.rbi.org.in/scripts/PublicationsView.aspx?id=10494

Reddy V. C. (2016). 12 Pillars' Framework for Successful Financial Inclusion in India, Indian Journal of Finance, 10(12), 27-43.

Serebrisky, T., \& Cavallo, E. (2016). Saving for Development: How Latin America and the Caribbean Can Save More and Better, Palgrave Macmillan. Retrieved from https://www.econstor.eu/bitstream/10419/181953/1/978-1-349-94929-8.pdf

Sharma, B. P., \& Singh, M. D. (2012). Knowledge Sharing Barriers: An Approach of Interpretive Structural Modeling, The IUP Journal of Knowledge Management, 10(3), $35-52$.

Singh, A. K., Singh, M. D., \& Sharma, B. P. (2013). Modeling of Knowledge Management Technologies: An ISM Approach, The IUP Journal of Knowledge Management, 11 (3), 41-55.

Talib, F., \& Rahman, Z. (2015). An interpretive structural modeling for sustainable healthcare quality dimensions in-hospital services, International Journal of Qualitative Research in Services, 2(1), 28-46.

Thyagarajan, G., \& Nair, J. (2016). Financial Inclusion In India - A Review, International Journal of Science Technology and Management, 5(8), 426-432.

Tripathi,R.,Yadav, N., \& Shastri, R. K. (2016), Financial Inclusion in India through Pradhan Mantri Jan DhanYojana: An Empirical Analysis of Statistical Evidence, Indian Journal of Finance 10(10), 42-55.

Yunna, W., Qing, B., \& Ping L. (2012). The ISM Analysis on Influence Factors of Cost Control in the Wind Power Construction Project, Physics Procedia, 24, 587-590.

\section{Copyrights}

Copyright for this article is retained by the author(s), with first publication rights granted to the journal. This is an open-access article distributed under the terms and conditions of the Creative Commons Attribution license (http://creativecommons.org/licenses/by/4.0/) 